\title{
Spatio-temporal variations of sulfur dioxide concentrations in industrial and urban area via a new statistical approach
}

Landim, A. A; Teixeira Calesso, Elba; Agudelo Castañeda, Dayana Milena; Schneider, Ismael Luís; Silva Oliveira, Luis Felipe; Wiegand, Flavio; Kumar, Prashant.

\begin{abstract}
Sulfur dioxide $\left(\mathrm{SO}_{2}\right)$ is considered the most widespread pollutant that threatens environmental and human health. The purpose of this study is to propose a new method for evaluating the spatial variation of $\mathrm{SO}_{2}$ levels in the Metropolitan Area of Porto Alegre (MAPA). This method included use of Chi-square test to better identify the origin of $\mathrm{SO}_{2}$ sources. Additionally, results of the different methods applied allowed to analyze the temporal $\mathrm{SO}_{2}$ levels and their association with meteorological parameters. $\mathrm{SO}_{2}$ at five sampling sites (Esteio, Canoas, Charqueadas, Triunfo, and Gravataí) were measured during 2010-2015; using fluorescence $\mathrm{SO}_{2}$ automated analyzers. Results showed that Charqueadas had the highest average concentration $\left(\sim 15 \mathrm{\mu g} \mathrm{m}^{-3}\right)$, followed by Triunfo $\left(13 \mu \mathrm{g} \mathrm{m}^{-3}\right)$, Esteio $\left(6 \mu \mathrm{g} \mathrm{m}^{-3}\right)$, Canoas $\left(3 \mu \mathrm{g} \mathrm{m}^{-3}\right)$, and Gravataí $\left(2 \mu \mathrm{g} \mathrm{m}^{-3}\right)$. Chi-square test applied to $\mathrm{SO}_{2}$, and wind direction quadrants showed significant contribution of local emission sources. Seasonal variation revealed higher $\mathrm{SO}_{2}$ levels on cold days for most of the studied sites, except for Esteio site. Day-wise variations revealed higher $\mathrm{SO}_{2}$ concentration on weekdays than weekends for Esteio and Canoas sites, indicating traffic influence especially during the rush-hours. Annual averages analysis identified an increasing trend in $\mathrm{SO}_{2}$ concentrations, implying that applied emission control systems and technological improvement of engines and fuels were not sufficient and thus points out a need for better subsidies mechanisms to pollutant control and effective emission reduction strategies that decision makers, including environmental agencies, must make priority by considering the local realities.
\end{abstract}

\section{Keywords}

Air Pollution; Statistical Analysis; Sulfur Dioxide; Weekend Effect. 